\title{
Deconstruction project planning considering local environmental impacts
}

\author{
Anna Kühlen ${ }^{1}$, Rebekka Volk ${ }^{2}$, Julian Stengel ${ }^{3}$, Frank Schultmann ${ }^{4}$
}

\begin{abstract}
At present deconstruction project planning and related research focus mainly on economic issues including costs for equipment, workers and material disposal. Nevertheless, deconstruction of buildings can have major impacts on the local environment in terms of noise, dust and vibrations. Usually these environmental concerns are not included in deconstruction planning. But they can be harmful for humans, animals and the surrounding built environment. Analyses of different deconstruction techniques show major differences in noise, dust and vibrations. To use this potential to mitigate local environmental impacts, principals and deconstruction managers have to perform environmental conscious detailed deconstruction planning. In support of balancing these environmental issues with economic and technical aspects, a multi-criteria decision approach can help in the planning phase. In this paper a combination of the multi-criteria decision analys is methods Analytic Hierarchy Process (AHP) and Multi-Attribute Value Theory (MAVT) is embedded in a system for the planning of deconstruction projects based on deconstruction techniques applied to single building components. The structure of this system is described in detail, encompassing the procedure of modelling the overall planning and decision making process as well as the application of the decision making logic. Expert knowledge and experimental noise, dust and vibration measurements related to different deconstruction techniques form the system database. The system is exemplarily applied to deconstruction planning of a small one-level building. Finally, its possible future practical implementation is addressed.
\end{abstract}

Keywords: deconstruction, environmental impacts, multi-criteria, project planning, sustainability.

\section{Introduction}

Especially in cities, where space is limited and demographic and economic changes ask for adaptions in the spatial distribution of buildings, deconstruction of buildings becomes increasingly necessary (Shin et al. 2005, Couto and Couto 2007). Deconstruction is the last building life cycle stage, also often called 'demolition'" (ISO 22263:2008-01, Thomsen et

$1 \quad$ Research Associate, French-German Institute for Environmental Res earch (DFIU), Karlsruhe Institute of Technology, Hertzstr. 16, 76187 Karls ruhe, Germany, Tel: +49-721-60844691, Fax: +49-721-60844682, E-mail: anna.kuehlen@kit.edu.

2 Research Associate, Institute for Industrial Production (IIP), Karlsruhe Ins titute of Technology, Hertzstr. 16, 76187 Karlsruhe, Germany, Tel: +49-721-60844699, Fax: +49-721-60844682, E-mail: rebekka.volk@kit.edu.

3 Head of research group 'Sustainability of the built environment', Ins titute for Industrial Production (IIP), Karls whe Institute of Technology, Hertzstr. 16, 76187 Karls ruhe, Germany, Tel: +49-721-60844555, Fax: +49-721-60844682, E-mail: julian.stengel@kit.edu.

4 Professor, Institute for Indus trial Production (IIP), Karls ruhe Institute of Technology, Hertzstr. 16, 76187 Karlswhe, Germany, Tel: +49-721-60844469, Fax: +49-721-60844682, E-mail: frank.schultmann@kit.edu.

${ }^{5}$ In this research the term deconstruction is chosen. The terms deconstruction and demolition are used almost synonymously nowadays. Both terms describe the removal of a building/structure. In deconstruction ecologic aspects, such as the recycling of building materials, are explicitly considered. Today regulations 
al. 2011, Sánchez and Lauritzen 2006). Deconstruction activities are potentially the source of high impacts on the local environment, mainly noise, dust and vibrations (DIN-Standard 2000, Lippok and Korth 2007). These impacts can cause local health hazards (Haltenorth et al. 2007) and can harm the surrounding built environment. The extent of deconstruction related environmental impacts in the form of noise, dust and vibrations highly depends on and varies with applied deconstruction technologies (DIN-Standard 2000, Chen and Li 2006), i.e. a combination of equipment and deconstruction methods, as well as on building characteristics, such as building materials (Kühlen et al. 2014). The building characteristics are fixed by the exiting building. Hence, in planning of deconstruction projects decision on the applied single deconstruction techniques should be included to manage and mitigate local environmental impacts. This approach to manage and mitigate impacts on the local environment in deconstruction project planning becomes recently important. In the future it might become a key aspect of project quality in the course of sustainable development, encompassing an ecologic and social dimension besides the economic dimension.

As building deconstruction has project character, operational project planning tools and methods are applicable for detailed planning on activity-level. Nevertheless, current tools for operational deconstruction project planning manly focus on economic issues and do not explicitly consider local environmental impacts (Haltenorth et al. 2007). Consequently, the integration of local environmental impacts in operational deconstruction project planning and decision making is addressed in this research. First, approaches of operational deconstruction project planning and decision making in recent research are reviewed. Then an approach for multi-criteria decision support is presented, which takes account on environmental impacts in the selection of appropriate deconstruction techniques for the planning of single deconstruction activities.

\section{Recent research approaches of deconstruction project planning}

In general the deconstruction of buildings is little considered in science and research (Thomsen et al. 2011, Jain et al. 2008). A comprehensive overview of different qualitative and quantitative approaches of current research in the area of deconstruction is given in Xanthopoulos et al. 2012, including deconstruction project planning, besides construction and demolition waste management. The emphas is of this research is on project planning and decision making methods. Hence, studies mainly focusing on the management of deconstruction materials after the actual deconstruction process on site or on 'design for deconstruction' at the early design stage of new buildings are excluded in the review of recent research approaches. Only very few approaches allow detailed project planning of the single deconstruction activities using case study-based, quantitative, activity-related data about duration times, costs and resources (Schultmann and Rentz 2002, Seemann 2003, Schultmann 2003). The focus is on economic issues and impacts on the local environment in terms of noise, dust and vibrations are not considered here. Singly on strategic level environmental impacts are occasionally considered in the context of decision making (Kourmpanis et al. 2008a, Kourmpanis et al. 2008b, Chen und Li 2006, Anumba et al. 2003). With the help of methods of multi-criteria decision analysis (MCDA) decisions on the overall deconstruction project are made considering different-scaled, qualitative and quantitative economic and environmental aspects. Decisions are not made on single activities of the overall project and no detailed deconstruction-activity-related data of impacts on the local environment is available.

force the consideration of these ecologic aspects in demolition as well. Hence, the differentiation between these terms is limited. 
The review shows that up to now there are very few operational deconstruction planning approaches. These research approaches on operational level do not consider environmental impacts. Furthermore, MCDA methods have proven to be appropriate to make decisions considering diverse different-scaled economic and environmental aspects. Hence, an approach for operational deconstruction planning including multi-criteria decision making on single activities and considering local environmental impacts is developed. The planning approach requires deconstruction-activity-related data of impacts on the local environment. As related data in literature is rarely, data is generated from experimental noise, dust and vibration measurements related to different deconstruction techniques as well as expert knowledge.

\section{Multi-criteria decision support system for deconstruction planning}

In this section a syste $\mathrm{m}$ for the consideration of local environmental impacts in operational deconstruction planning is developed. Multi-criteria decision support is provided for single activities of the deconstruction project plan. The system can support principals and deconstruction managers in performing environmental conscious detailed deconstruction planning and decision making. In the following, relevant definitions related to deconstruction planning are outlined before the approach is described in detail.

\section{Definitions related to decons truction planning}

A deconstruction activity $\mathrm{j}$ is a unit of the overall deconstruction process based on a single component of the building shell. The activity duration is composed of three segments. The first segment $d_{j, f, b j}$ is the duration to deconstruct the component itself with the deconstruction technique $f$. The time $d_{j, \text { fsep }}$ required to separate and $d_{j, f, c r}$ to crush the material of the deconstruction unit to reach a high material quality for recycling are the second and third segment. $\mathrm{d}_{\mathrm{j}, \mathrm{fb} \mathrm{j}}$ depends on the material-related performance value $\mathrm{p}_{\mathrm{f}, \mathrm{b}_{\mathrm{j}}}$ $\left(\mathrm{h} / \mathrm{m}^{3}\right)$ of a deconstruction technique $\mathrm{f}$ deducted from technique-specific and materialrelated performance values in literature (Weimann et al. 2013, Lippok und Korth 2007, Seemann 2003, Rentz et al. 2002, Willkomm 1990) and the material $b_{j}$ of the building shell component as well as the material volume $\mathrm{m}_{\mathrm{j}, \mathrm{bj}}\left(\mathrm{m}^{3}\right)$ of this component the activity is related to.

$\mathrm{d}_{\mathrm{j}, \mathrm{f}, \mathrm{bj}}=\mathrm{p}_{\mathrm{f}, \mathrm{bj}_{\mathrm{j}}} \mathrm{m}_{\mathrm{j}, \mathrm{bj}}$

$d_{j, f, b j, s e p}\left(d_{j, f, b j, c r}\right.$ respectively) depends on of the material-related performance value $p_{\text {sep, }, \mathrm{j}}$ $\left(\mathrm{p}_{\mathrm{cr}, \mathrm{bj}}\right)\left(\mathrm{h} / \mathrm{m}^{3}\right)$ to separate (crush) the building component material $\mathrm{b}_{\mathrm{j}}$ (cf. Lippok und Korth 2007), the component material volume $\mathrm{m}_{\mathrm{j}, \mathrm{bj}}\left(\mathrm{m}^{3}\right)$ and the classification number $\mathrm{gs}_{\mathrm{f}, \mathrm{bj}}\left(\mathrm{gc}_{\mathrm{f}, \mathrm{j}}\right)$, which is based on practical experiences and expert knowledge and expresses the degree of pre-separation (pre-crushing) of a deconstruction technique $f$ applied to material $b_{j}$.

$\mathrm{d}_{\mathrm{j}, \mathrm{fbj}, \mathrm{sep}}=\mathrm{p}_{\mathrm{sep}, \mathrm{b}_{\mathrm{j}}}{ }^{\mathrm{g}} \mathrm{gs}_{\mathrm{f}, \mathrm{bj}} * \mathrm{~m}_{\mathrm{j}}\left(\mathrm{d}_{\mathrm{j}, \mathrm{fbj}, \mathrm{cr}}=\mathrm{p}_{\mathrm{cr}, \mathrm{bj}_{\mathrm{j}}} \mathrm{gc}_{\mathrm{f}, \mathrm{bj}} * \mathrm{~m}_{\mathrm{j}}\right)$

Whereas, the material and the volume are fixed characteristics of the existing building, the technique can be chosen from different alternatives due its material-related suitability (DIN-Standard 2000, Lippok and Korth 2007). A technique is a combination of the deconstruction method, such as gripping, and equipment. Table 1 lists an extract of the relevant alternative deconstruction techniques listed in DIN-Standard 2000. 
Table 1. Deconstruction techniques

\begin{tabular}{|c|c|c|c|c|}
\hline \multicolumn{2}{|c|}{ Deconstruction technique $\mathrm{f}^{6}$} & \multicolumn{2}{|c|}{ Equipment } & \multirow[t]{2}{*}{ Method } \\
\hline Name & Abbreviation & Support frame & Attachment & \\
\hline $\begin{array}{c}\text { Gripping with } \\
\text { hydraulic excavator }\end{array}$ & Grip & Hydraulic excavator & $\begin{array}{l}\text { Deconstruction } \\
\text { grab }\end{array}$ & Gripping \\
\hline $\begin{array}{l}\text { Mortising with } \\
\text { hydraulic excavator }\end{array}$ & Mort & Hydraulic excavator & Hammer & Mortising \\
\hline $\begin{array}{l}\text { Press-cutting with } \\
\text { hydraulic excavator }\end{array}$ & Press-Cut & Hydraulic excavator & Pincers & $\begin{array}{l}\text { Press } \\
\text { cutting }\end{array}$ \\
\hline
\end{tabular}

Especially deconstruction of the building shell can generate environmental impacts in the form of noise, dust and vibrations (DIN-Standard 2000). Hence, the shell of the existing building is defined as deconstruction object. The deconstruction object is modelled based on single vertical and horizontal building shell components (table 2). Appropriate deconstruction techniques are identified depending on the material, thickness and the height above ground of these single components. Furthermore, the available space on site influences the suitability of the techniques (DIN-Standard 2000, Lippok and Korth 2007).

Table 2. Selected building shell components constituting the deconstruction object

\begin{tabular}{ccccc}
\hline \multirow{2}{*}{ Structure type } & \multicolumn{2}{c}{ Vertical components } & \multicolumn{2}{c}{ Horizontal components } \\
\cline { 2 - 5 } & Name & Material $\left(\mathrm{b}_{\mathrm{j}}\right)$ & Name & Material $\left(\mathrm{b}_{\mathrm{j}}\right)$ \\
\hline $\begin{array}{c}\text { Steel frame } \\
\text { construction }\end{array}$ & Column & Steel & Beam & Steel \\
$\begin{array}{c}\text { Masonry } \\
\text { construction }\end{array}$ & Wall & Masonry: & Slab & $\begin{array}{c}\text { Reinforced } \\
\text { concrete }\end{array}$ \\
$\begin{array}{c}\text { with reinforced } \\
\text { concrete slab }\end{array}$ & & $\bullet$ Brick & & \\
$\begin{array}{c}\text { Timber frame } \\
\text { construction }\end{array}$ & Column & $\begin{array}{c}\text { Concrete } \\
\text { Natural stone }\end{array}$ & Beam & Timber \\
\hline
\end{tabular}

The deconstruction sequence is performed reverse of construction, top-down and building le vel-wise, according to an actual popular deconstruction approach (Schultmann 1998, Lippok and Korth 2007). Furthermore, it is assumed that only one activity is performed at a given time.

\section{An approach for decision making in ope rational de cons truction planning}

With the help of the following in detail described approach of decision making in operational deconstruction planning, it is aimed to select one technically, economically and environmentally appropriate deconstruction technique for each activity of the deconstruction process of the building shell. The approach can be divided into two parts

\footnotetext{
${ }^{6}$ Combination of equipment and method.
} 
(see figure 1). First, the overall planning and decision making process is modelled, including the single deconstruction activities. Within this context the technically feasible deconstruction alternatives of each activity are determined and their economic and ecologic characteristics are calculated. Secondly, the decision making logic is applied, which is a combination of the multi-criteria decision analys is methods Analytic Hierarchy Process (AHP) and Multi-Attribute Value Theory (MAVT). Here decision is made on the appropriate deconstruction technique of each single activity based on the calculated economic and ecologic characteristics.

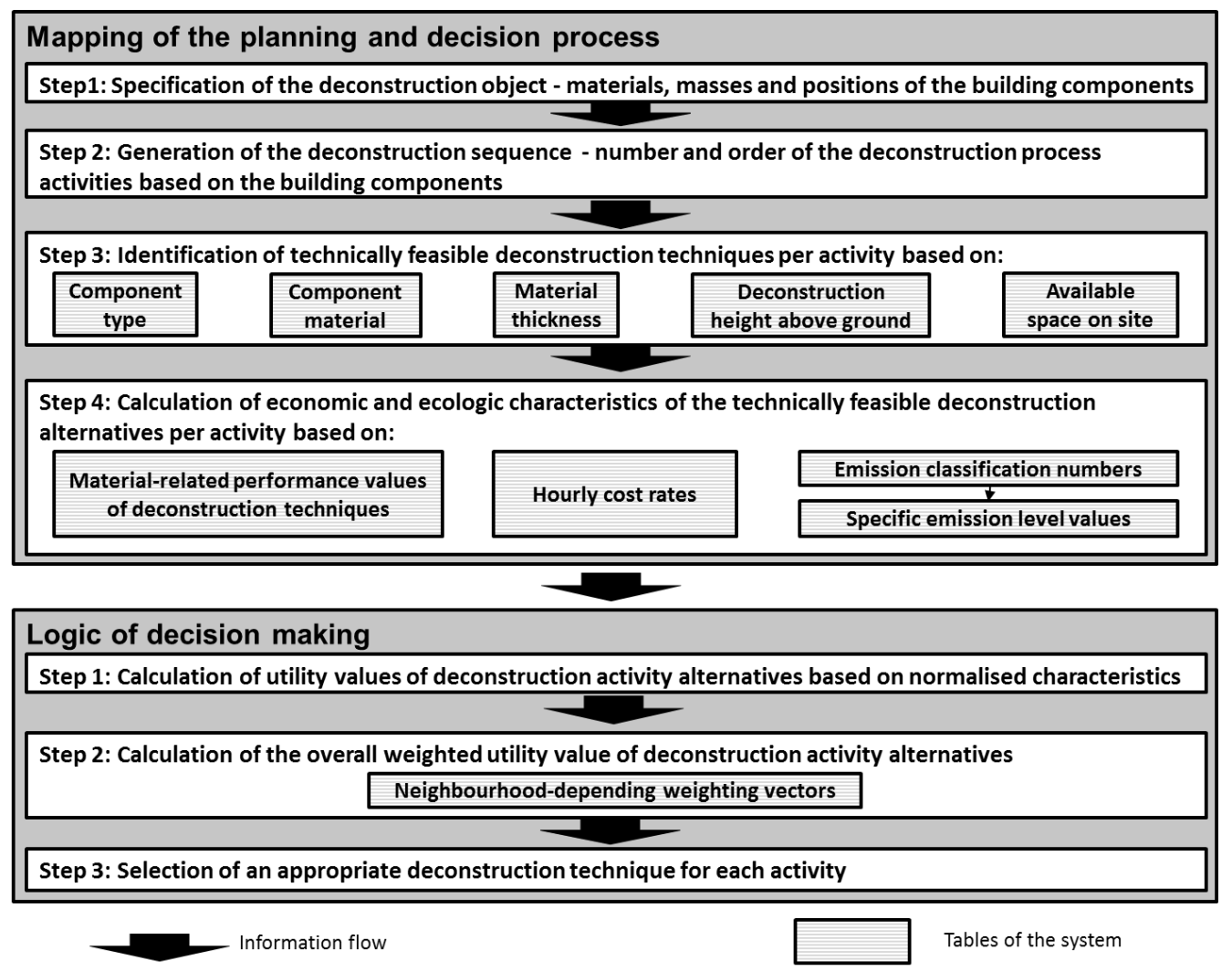

Figure 1. Process mapping and decision logic

\section{Mapping of the planning and decision process}

Step 1: the deconstruction object is specified building level- and component-specific, including the materials $b_{j}$ and volumes $m_{j, b j}$ of single components of the building shell.

Step 2: one activity $\mathrm{j}$ of the deconstruction process is assigned to each component and the deconstruction sequence is generated as predefined top-down and level-wise with only one activity at a time.

Step 3: for each activity $\mathrm{j}$ the technically feasible deconstruction techniques $\mathrm{f}$ are identified, which have to be evaluated by the economic and ecologic criterion $\mathrm{k}$ and respective sub-criteria i (economic: costs; ecologic: noise, dust, vibrations) for decision making.

Step 4: the economic and ecologic characteristics of each technically feasible deconstruction alternative per activity are calculated. The economic characteristic $\mathrm{s}_{\mathrm{j}, \mathrm{f}, \mathrm{b}, \mathrm{j}, \mathrm{econ}}$ of activity $\mathrm{j}$ performed with the alternative deconstruction technique $\mathrm{f}$ (including related tasks of material separation and crushing) is defined as the sum of variable/durationdependent costs to hire equipment (hourly rate of equipment $\cos t \mathrm{c}_{\mathrm{f} \text {,equip }} / \mathrm{c}_{\text {sep,equip }} / \mathrm{c}_{\mathrm{cr} \text {, equip }}$ (cf. 
BGL 2007)) and costs for workers ${ }^{7}$ (hourly rate of labor costs $c_{\text {labor }}$ and amount $n_{f}$ of required workers dependent on the technique (Lippok and Korth 2007)). For material separation and crushing only one worker is required at a time.

$\mathrm{s}_{\mathrm{j}, \mathrm{f}, \mathrm{bj}, \text { econ }}=\mathrm{d}_{\mathrm{j}, \mathrm{f}, \mathrm{bj}} *\left(\mathrm{c}_{\mathrm{f} \text {,equip }}+\mathrm{c}_{\text {labor }} * \mathrm{n}_{\mathrm{f}}\right)+\mathrm{d}_{\mathrm{j}, \mathrm{f} \text { bj,sep }} *\left(\mathrm{c}_{\text {sep,equip }}+\mathrm{c}_{\text {labor }}\right)+\mathrm{d}_{\mathrm{j}, \mathrm{fbj}, \mathrm{cr}} *\left(\mathrm{c}_{\mathrm{cr} \text {,equip }}+\mathrm{c}_{\text {labor }}\right)$

Furthermore three ecologic characteristics are defined with respect to the identified major deconstruction-related impacts on the local environment, namely emissions of noise, dust and vibrations. The characteristic of noise emissions $\mathrm{s}_{\mathrm{j}, \mathrm{f}, \mathrm{b}, \mathrm{noise}}$ of activity $\mathrm{j}$ performed with the alternative deconstruction technique $f$ is a product of the activity-related durations $d_{j, f, b j}$, $d_{j, f, b j, s e p}$ and $d_{j, f, b j, c r}$ and the specific, material-related values of noise levels $1_{f, b j, n o i s e}$ of the applied deconstruction technique $\mathrm{f}$ and $1_{\mathrm{sep}, \mathrm{b}, \text { noise }}$ and $\mathrm{l}_{\mathrm{cr}, \mathrm{b} \text {, noise }}$ of related tasks of separating and crushing material to reach a high material quality for recycling.

$\mathrm{s}_{\mathrm{j}, \mathrm{fb} \mathrm{b}, \text { noise }}=\mathrm{d}_{\mathrm{j}, \mathrm{f}, \mathrm{b} \mathrm{j}} * \mathrm{l}_{\mathrm{f}, \mathrm{bj} \text {, noise }}+\mathrm{d}_{\mathrm{j}, \mathrm{fb} \mathrm{b}, \text { sep }} * 1_{\mathrm{sep}, \mathrm{bj}, \text { noise }}+\mathrm{d}_{\mathrm{j}, \mathrm{fb} \mathrm{b}, \mathrm{cr}} * 1_{\mathrm{cr}, \mathrm{bj}, \text { noise }}$

The characteristics of dust and vibration emissions $\left(\mathrm{s}_{\mathrm{j}, \mathrm{f}, \mathrm{b}, \text { dust }}\right.$ and $\left.\mathrm{s}_{\mathrm{j}, \mathrm{f}, \mathrm{bj}, \mathrm{vib}}\right)$ are calculated likewise with specific, material-related values of dust levels $1_{\mathrm{f}, \mathrm{bj}, \text { dust }}, 1_{\mathrm{sep}, \mathrm{bj} \text {,dust }}$ and $1_{\mathrm{cr}, \mathrm{bj} \text {,dust }}$ respective vibration levels $1_{\mathrm{f}, \mathrm{b}, \mathrm{vib}}, 1_{\mathrm{sep}, \mathrm{bj}, \mathrm{vib}}$ and $1_{\mathrm{cr}, \mathrm{bj}, \mathrm{vib}}$ of the applied deconstruction technique as well as of related tasks of material separation and crushing. To date neither are specific, material-related values of emission levels existing nor is related required data to generate these values sufficiently available in literature. Hence, the specific, material-related emission levels of noise, dust and vibrations are deducted from semi-quantitative, ninestage classification numbers according to the human sense and legal critical limits (0: no emissions/not annoying, 1: little emission/little annoying, 2: medium emissions/medium annoying, 3: high emissions/annoying, 4: very high emissions/painful, and respective midpoints: e.g. 1.5) gained from prior experiences, expert knowle dge and experimental noise, dust and vibration measurements. Figure 2 shows the classification numbers of noise, dust and vibration emissions of the extracted alternative deconstruction techniques (cf. table 1) exemplary applied to the material brick.

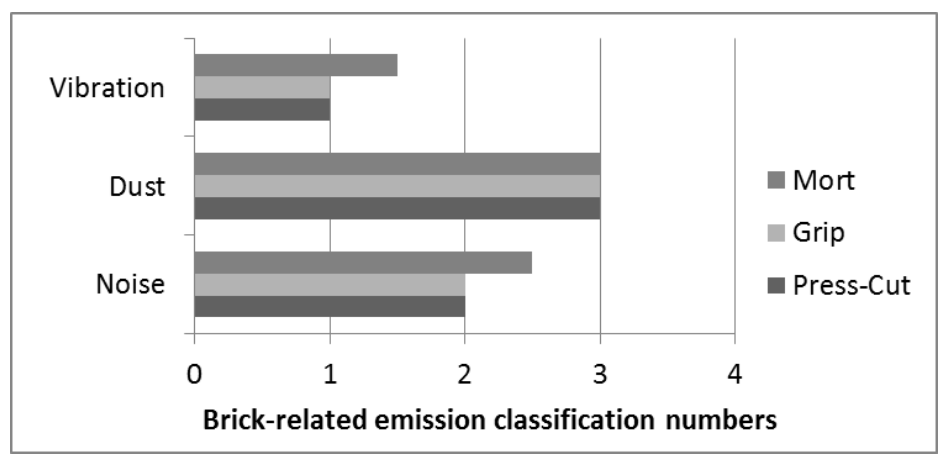

Figure 2. Emission classification numbers of deconstruction techniques applied on the building material brick as an example

According to the human sense and legal critical limits the classification numbers represent intervals of emission levels, which differ in interval size. This has to be considered in determination of the specific values of emission levels. Hence, in this determination of specific emission level values (e.g. $1_{\mathrm{f}, \mathrm{bj}, \text { noise }}$ ) the differences between the

\footnotetext{
${ }^{7}$ Costs for one worker are the calculated average wage of a skilled construction worker and an operator on a German construction site.
} 
mean value of each interval and the emission level assigned to the classification number " 0 " is calculated. For instance, noise emissions less than $70 \mathrm{~dB}(\mathrm{~A})$ are classified as " 0 ". Emissions between 70 and $85 \mathrm{~dB}(\mathrm{~A})$ are assigned to " 1 ". This interval has a mean value of $77.5 \mathrm{~dB}(\mathrm{~A})$ with a difference of $7.5 \mathrm{~dB}(\mathrm{~A})$ to $70 \mathrm{~dB}(\mathrm{~A})$ ("0"). A noise level difference $(\Delta \mathrm{L})$ of $7.5 \mathrm{~dB}(\mathrm{~A})$ corresponds to an increase of the experienced noise by humans of $0.7 .{ }^{8}$ Hence, $1_{\mathrm{f}, \mathrm{bj}, \text { noise }}$ is set to 0.7 .

\section{Logic of decision making}

Decision making on the appropriate deconstruction technique of each single activity on the basis of the calculated economic and ecologic characteristics with the help of AHP and MAVT encompasses three steps described in the following.

Step 1: utility values of the deconstruction alternatives per activity are calculated. Therefore, utility values $\mathrm{v}_{\mathrm{i}, \mathrm{j}, \mathrm{f}}$ with respect to each economic and ecologic sub-criterion $\mathrm{i}$ are calculated for each applied alternative deconstruction technique $\mathrm{f}$ (enclosing related tasks of material separation and crushing) of activity $\mathrm{j}$. Within this context the economic and ecologic characteristics of each alternative have to be transferred to a common scale by normalization to enable the comparison of alternatives of an activity based on these different-scaled characteristics. Thus, for each characteristic, the maximum (max $\mathrm{s}_{\mathrm{j}, \mathrm{f}, \mathrm{bj}, \text { econ/ecol }}$ ) and minimum ( $\mathrm{min} \mathrm{s}_{\mathrm{j}, \mathrm{fb} \text {, econ/ecol }}$ ) related to an activity is identified. The maximum characteristic is set equal to 0 and the minimum characteristic equal to 1 . The other normalized characteristics of each activity and each attribute are calculated based on a linear scale between the identified maximum and minimum. Following section describes this proceeding using the exemplary application of the deconstruction planning system.

Step 2: the overall weighted values of the technique alternative $f$ of each deconstruction

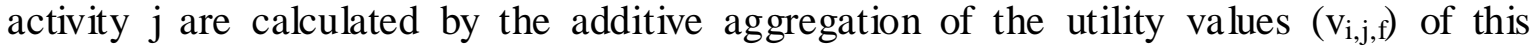
alternative with respect to each economic and ecologic sub-criterion i multiplied by the weight of this sub-criterion $\left(\mathrm{w}_{\mathrm{i}, \mathrm{k}}\right)$.

$\mathrm{V}_{\mathrm{j}, \mathrm{f}}=\sum \mathrm{w}_{\mathrm{i}, \mathrm{k}} * \mathrm{v}_{\mathrm{i}, \mathrm{j}, \mathrm{f}}$

The weight $\mathrm{w}_{\mathrm{i}, \mathrm{k}}$ represents the importance of the economic and ecologic sub-criteria $\mathrm{i}$, which is the preferences of the decision maker depending on the neighborhood characteristics of the individual deconstruction site. For the calculation of weights AHP (Saaty 1980) is applied. A hierarchy of criteria and sub-criteria is built as shown in table 3. One weight $\mathrm{w}_{\mathrm{i}, \mathrm{k}}$ is the product of the weighting factor $\mathrm{w}_{\mathrm{i}}$ of one sub-criterion $\mathrm{i}$ and the weighting factor $\mathrm{w}_{\mathrm{k}}$ of its higher criterion $\mathrm{k}$.

$\mathrm{w}_{\mathrm{i}, \mathrm{k}}=\mathrm{w}_{\mathrm{i}}{ }^{*} \mathrm{w}_{\mathrm{k}}$, with $\sum \mathrm{w}_{\mathrm{i}, \mathrm{k}}=1, \mathrm{w}_{\mathrm{i}, \mathrm{k}}>=0$ for all $\mathrm{i}$

The sensitivity of the deconstruction site neighborhood influences the weighting factor height of each criterion and sub-criterion. For instance, table 3 shows a possible weighting vector for a residential neighborhood, which is very sensitive to noise and sensitive to dust and the economic aspects are less important, but should be considered as well.

Step 3: the appropriate deconstruction technique for each activity is selected by selecting the alternative with the highest overall weighted utility value.

\footnotetext{
${ }^{8}$ Calculation of the increase in in experienced noise: $1-2^{(\Delta L / 10)}$ (cf. Sengpielaudio 2014).
} 
Table 3. Assumed exemplary weights for a deconstruction project in a residential neighborhood

\begin{tabular}{ccccc}
\hline $\begin{array}{c}\text { Criteria } \\
(\mathrm{k})\end{array}$ & $\begin{array}{c}\text { Weighting factors } \\
\text { of the criteria }\left(\mathrm{w}_{\mathrm{k}}\right)\end{array}$ & Sub-criteria (i) & $\begin{array}{c}\text { Weighting factors of } \\
\text { the sub-criteria }\left(\mathrm{w}_{\mathrm{i}}\right)\end{array}$ & $\begin{array}{c}\text { Weight } \\
\left(\mathrm{w}_{\mathrm{i}, \mathrm{k}}\right)\end{array}$ \\
\hline Economic & 0.2 & Costs & 1 & 0.20 \\
\hline \multirow{3}{*}{ Ecologic } & 0.8 & Noise emissions & 0.7 & 0.56 \\
& & Dust emissions & 0.3 & 0.24 \\
& & Vibration emissions & 0 & 0 \\
\hline
\end{tabular}

\section{Exemplary application of the deconstruction planning system}

The model is applied using the example of the deconstruction of a small one level building, consisting of four brick walls (volume of each wall: $15 \mathrm{~m}^{3}$ ) and one reinforced concrete slab $\left(10 \mathrm{~m}^{3}\right)$. This building specification is the first step of mapping the planning and decision process. In the second step the deconstructed sequence is defined top-down, starting with the slab followed by the walls. In the example the walls can be deconstructed subsequently, each wall separately or two walls at a time as one activity. Both options are analyzed as alternative deconstruction activities in the following. Alternative deconstruction techniques are those listed in table 1. The technical feasibility of the techniques due to component type and material type and thickness, due to the deconstruction height above ground and available space on site is given. Table 4 shows the result of the third and fourth step, the alternative activities $\mathrm{j}$, including the technically feasible alternative deconstruction techniques applied to the components (reinforced concrete slab, brick walls) as well as respective economic and ecologic characteristics.

After the planning and decision process is mapped the decision making logic is applied. Here in the first step, the utility values $v_{i, j, f}$ with respect to each economic and ecologic sub-criterion $i$ for each alternative deconstruction technique $f$ of activity $j$ are calculated based on the activity-related characteristics in table 4. Therefore the characteristics are normalized. For instance, the utility value of press-cutting of two walls at once due to the sub-criterion noise ( $\left.\mathrm{v}_{\text {noise-emissions,press-cut-2-brick-walls,press-cut }}\right)$ result in $0.95((50.4-36.0) /(50.4-$ $35.2)=0.95$.

Table 4. Characteristics of the example alternative deconstruction activities ${ }^{9}$

\begin{tabular}{|c|c|c|c|c|c|}
\hline \multirow{2}{*}{\multicolumn{2}{|c|}{ Alternative activities $\mathrm{j}$}} & \multicolumn{4}{|c|}{ Activity-related characteristics } \\
\hline & & Economic & & Ecologic & \\
\hline $\begin{array}{l}\text { Building } \\
\text { component }\end{array}$ & $\begin{array}{l}\text { Component-applied } \\
\text { alternative } \\
\text { deconstruction } \\
\text { techniques } \mathrm{f}^{10}\end{array}$ & $\begin{array}{c}\text { Costs }(€) \\
\mathrm{s}_{\mathrm{j}, \mathrm{f}, \mathrm{bj}, \mathrm{econ}}\end{array}$ & $\begin{array}{c}\text { Noise } \\
\text { (emissions } \\
\text { per } \\
\text { activity) }\end{array}$ & $\begin{array}{c}\text { Dust } \\
\text { (emissions } \\
\text { per } \\
\text { activity) }\end{array}$ & $\begin{array}{c}\text { Vibration } \\
\text { (emissions } \\
\text { per } \\
\text { activity) }\end{array}$ \\
\hline
\end{tabular}

${ }^{9}$ Characteristics are calculated by the system with the above described approach. System variables, such as material-related performance values (e.g. $\mathrm{p}_{\mathrm{f}, \mathrm{bj}}$ ), duration-dependent costs (e.g. $\mathrm{c}_{\mathrm{f} \text {, quip }}$ ) and specific, material-related values of emission levels (e.g. $1_{\mathrm{f}, \mathrm{bj}, \text { noise }}$ ) are based on literature data, experimental noise, dust and vibration measurements related to different deconstruction techniques as well as expert knowledge.

${ }^{10}$ Including related tasks of material separation and crushing to reach a high material quality for recycling. 


\begin{tabular}{|c|c|c|c|c|c|c|}
\hline & & & & $\mathrm{S}_{\mathrm{j}, \mathrm{f}, \mathrm{b} \mathrm{j}, \text { noise }}$ & $\mathrm{S}_{\mathrm{j}, \mathrm{f}, \mathrm{bj}, \text { dust }}$ & $\mathrm{S}_{\mathrm{j}, \mathrm{f}, \mathrm{f} \mathrm{j}, \mathrm{vib}}$ \\
\hline \multirow{2}{*}{$\begin{array}{l}10 \mathrm{~m}^{3} \\
\text { reinforced } \\
\text { concrete } \\
\text { slab }\end{array}$} & & Mort slab & 558.8 & 23.3 & 3.2 & 7.1 \\
\hline & & Press-Cut slab & 412.5 & 17.1 & 2.4 & 1.5 \\
\hline \multirow{6}{*}{$\begin{array}{l}4 \times 15 \mathrm{~m}^{3} \\
\text { brick walls }\end{array}$} & \multirow{3}{*}{$\begin{array}{l}\text { Each } \\
\text { wall } \\
\text { separate } \\
11\end{array}$} & Grip 1 wall & 1653.0 & 45.3 & 9.6 & 4.5 \\
\hline & & Mort 1 wall & 1737.0 & 50.4 & 9.6 & 6.4 \\
\hline & & $\begin{array}{c}\text { Press-Cut } 1 \\
\text { wall }\end{array}$ & 1578.0 & 35.2 & 8.6 & 4.7 \\
\hline & \multirow{3}{*}{$\begin{array}{l}\text { Two } \\
\text { walls at } \\
\text { a time }^{12}\end{array}$} & Grip 2 walls & 1653.0 & 45.8 & 8.7 & 5.2 \\
\hline & & Mort 2 walls & 1737.0 & 46.9 & 8.7 & 8.7 \\
\hline & & $\begin{array}{c}\text { Press-Cut } 2 \\
\text { walls }\end{array}$ & 1578.0 & 36.0 & 7.1 & 5.9 \\
\hline
\end{tabular}

In the second step, the overall weighted utility values of the technique alternative $f$ of each deconstruction activity $\mathrm{j}$ are calculated. The importance for decision making of the activity performance related to the economic and ecologic criterion $\left(\mathrm{w}_{\mathrm{k}}\right)$ and respective sub-criteria $\left(\mathrm{w}_{\mathrm{i}}\right)$ is depending on the neighborhood characteristics of the individual deconstruction site. With subject to the neighborhood different deconstruction activity alternatives might be more or less suitable. AHP (Saaty 1980) is applied to display the preferences of the decision maker by weights $\left(\mathrm{w}_{\mathrm{i}, \mathrm{k}}\right)$. For instance, if the neighborhood around the deconstruction site has buildings or facilities in buildings, which are highly sensitive to vibrations and minimal vibrations is the single criterion, gripping of each single wall successively is the most appropriate technique with an overall utility value of 1 (figure 3). However, if the deconstruction project takes place in a residential neighborhood and the exemplary weights of table 3 represent the decision maker preferences, presscutting of two walls at once has the highest overall utility value (figure 3 ). To deconstruct the slab, press-cutting suits better than mortising in both neighborhood scenarios.

\footnotetext{
${ }^{11} 1$ machine, 2 workers

122 machines, 4 workers
} 


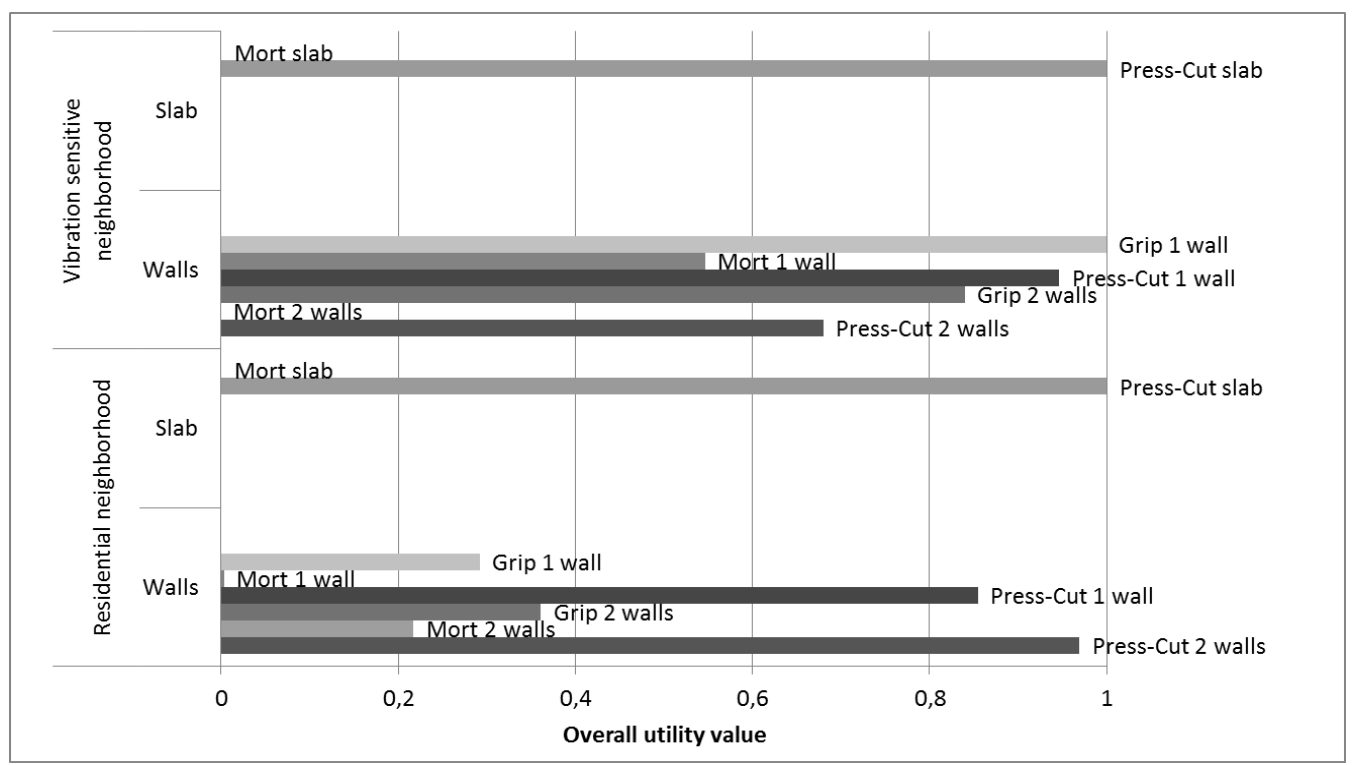

Figure 3. Overall utility values of the example alternative activities, when performed in different neighborhoods

In the third step, the system selects the alternative with the highest overall utility value for each deconstruction activity/the deconstruction of each building component (in the scenario of a residential neighborhood: press-cutting of the reinforced concrete slab and press-cutting of two brick walls at once).

These selected activities can be included into a project schedule. The resulting schedule of the deconstruction project as a Gantt chart and the related distribution of the emission levels over the project time are illustrated in figure 4.

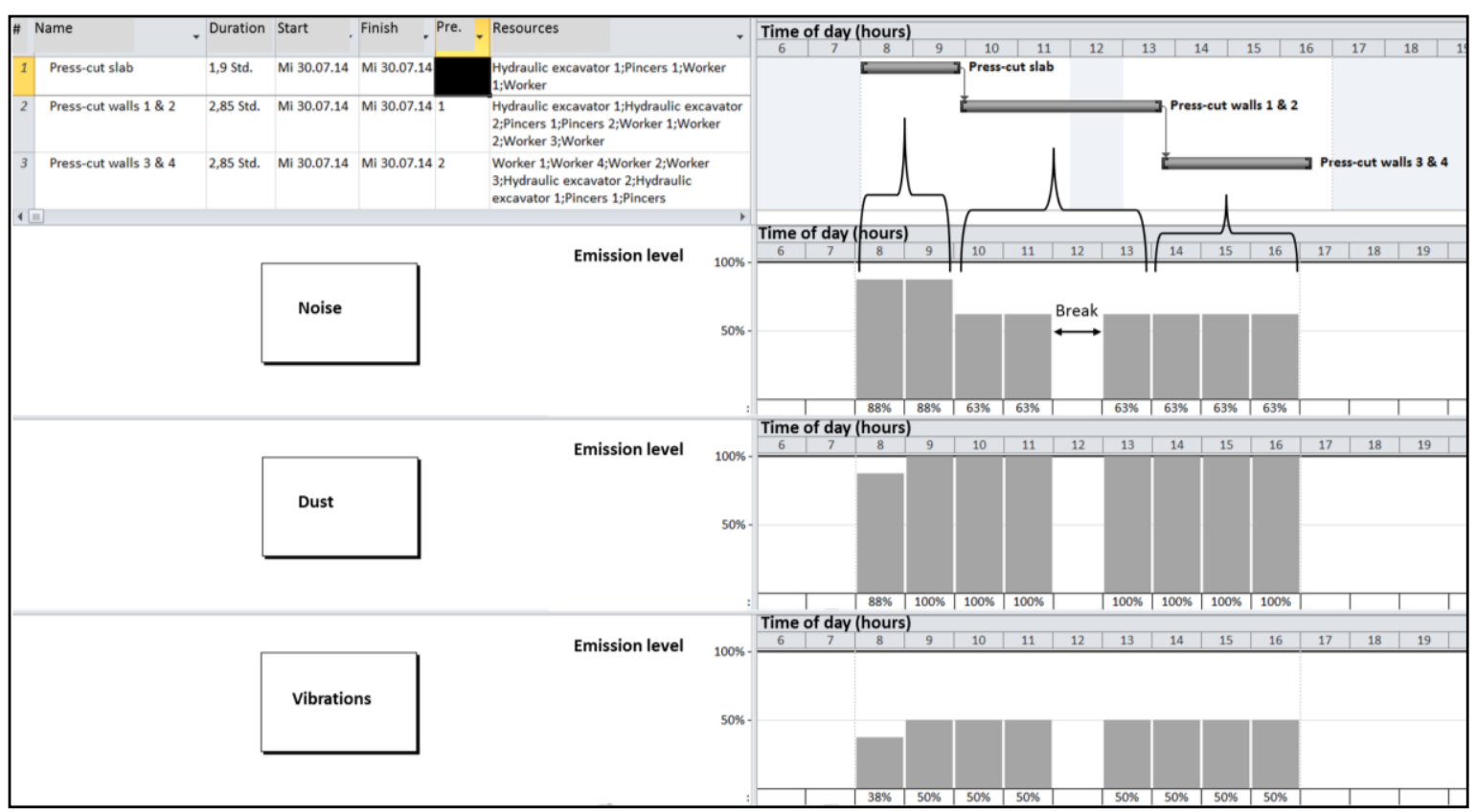

Figure 4. Deconstruction project Gantt chart and distribution of emission levels (scheduled in Microsoft Project) 


\section{Conclusions}

To mitigate local environmental impacts in terms of noise, dust and vibrations caused by deconstruction projects, which can be harmful for humans, animals and the surrounding built environment, principals and deconstruction managers have to perform environmental conscious detailed deconstruction planning. A multi-criteria decision support system for deconstruction planning is provided, which is based on expert knowledge and data from literature and experimental noise, dust and vibration measurements related to different deconstruction techniques. The system supports decision makers in selecting an appropriate technique while balancing economic and environmental issues based on technical feasibility and by considering the neighborhood of the deconstruction site. The system allows detailed/hourly analysis of alternative deconstruction techniques due to the single, independent and partly nonlinear local emissions noise, dust and vibrations. The system model was exemplarily applied to show the unlike environmental impacts caused by alternative activities of the overall deconstruction process and the importance to consider neighborhood characteristics and their differing sensitivities.

As building deconstruction becomes increasingly necessary and project planners and decision makers have to be aware of related possible impacts on the local environment, the practical implementation of the decision support into deconstruction planning is aimed in future. For this purpose the system has to be connected with current available instruments and software for deconstruction project planning and scheduling.

\section{References}

Anumba, C., Abdullah, A., Fesseha, T., 2003. Selection of demolition techniques: A case study of the Warren Farm Bridge. In: Structural Survey, 21(1), 36-48.

Bertsch, V., 2008. Uncertainty Handling in Multi-Attribute Decision Support for Industrial Risk Management. University of Karlsruhe (TH).

BGL (Baugeräteliste), 2007. Technisch-wirtschaftliche Baumaschinendaten. (Technical and economic data of construction equipment). Ed. Hauptverband der Deutschen Bauindustrie e.V..

Chen, Z. and Li, H., 2006. Environmental Management in Construction - A quantitative approach. New York, Taylor \& Francis.

Couto, J.P. and Couto, A.M., 2007. Reasons to consider the deconstruction process as an important practice to sustainable construction. In: Proceedings of SB07 Sustainable Construction, Materials and Practices. Portugal.

Kühlen, A., Stengel, J., Volk, R., Schultmann, F., Reinhardt, M., Schlick, H., Haghsheno, S., Mettke, A., Asmus, S., Harzhe im, J., 2014. Minimierung von Umweltbelastungen (Lärm, Staub, Erschütterungen) beim Abbruch von Hoch-/Tiefbauten und Schaffung hochwertiger Recyclingmöglichkeiten für Materialien aus Gebäudeabbruch Endbericht zur 2. Phase des Forschungsprojekts. Gefördert durch die Deutsche Bundesstiftung Umwelt (DBU), unpublished project report, Karlsruhe, August, 2014.

DIN-Standard, 2000. DIN 18007:2000-05: Demolition works - Concepts, procedures, fields of application.

Haltenorth, I., Weber, L., Leistner, P., Mehra, S., 2007. Neuartige Maßnahmen zur Minderung von Baulärm - Neuartige Maßnahmen zur Minderung von Baulärm Systeme, Methoden, Wirkungen. 
ISO 22263:2008-01: Organization of information about construction works - Framework for management of project information. Beuth.

Jain, R., George, R., Webster, R., 2008. Sustainable deconstruction and the role of know ledge-based systems. In: International Journal of Environmental Technology and Management 8(2-3): 261-274.

Kourmpanis, B., Papadopoulos, A., Moustakas, K., Kourmoussis, F., Stylianou, M., Loizidou, M., 2008a. An integrated approach for the management of demolition waste in Cyprus. In: Waste Management and Research, 26(6), 573-581.

Kourmpanis, B., Papadopoulos, A., Moustakas, K., Stylianou, M., Haralambous, K.J., Loizidou, M., 2008b. Preliminary study for the management of construction and demolition waste. In: Waste Management and Research, 26 (3), pp. 267-275.

Lippok, J. and Korth, D., 2007. Abbrucharbeiten. Verlagsgesellschaft Rudolf Müller GmbH \& Co. KG, 2nd Edition, Köln.

Rentz, O., Seemann, A., Reass, C., Schultmann, F., 2002. Entwicklung optimierter Rückbau- und Recyclingverfahren durch Kopplung von Gebäudedemontage und Bauschuttaufbereitung - Zwischenbericht. Gefördert durch die Deutsche Bundesstiftung Umwelt (DBU), Karlsruhe, 2002.

Saaty, T.L., 1980. The Analytic Hierarchy Process. McGraw Hill, New York, 1980.

Sánchez, I.G., Lauritzen, E.K, 2006. IRMA: A European project for a sustainable City Concept.

Schultmann, F., 2003. A model-based approach for the management of deconstruction projects. In: International Electronic Journal of Construction, Special Issue on the Future of Sustainable Construction, 1-22.

Schultmann, F. and Rentz, O., 2002. Scheduling of deconstruction projects under resource constraints. In: Construction Management and Economics, 20(5): 391-401.

Seemann, A., 2003. Entwicklung integrierter Rückbau- und Recyclingkonzepte für Gebäude - ein Ansatz zur Kopplung von Demontage, Sortierung und Aufbereitung. Shaker Verlag, Aachen.

Sengpielaudio 2014. The human perception of loudness. Available from: http://www.sengpielaudio.com/calculator-loudness.htm [Accessed 11 August 2014].

Shin, J. H., Lee, Y. H., Kwon, W. T., Kim, Y. J., 2005. A large scale demolition in a densely populated urban area - A case study. Bridge management 5: inspection, maintenance, assessment and repair. In: Proceedings of the 5th International Conference on Bridge Management, University of Surrey, 11-13 April 2005, 195-202.

Thomsen, A., Schultmann F., Kohler, N., 2011. Deconstruction, demolition and destruction. In: Building Research and Information, 39(4), 327-332.

Weimann, K., Matyschik, J., Adam, C., Schulz, T., Linß, E., Müller, A., 2013. Optimierung des Rückbaus/Abbaus von Gebäuden zur Rückgewinnung und Aufbereitung von Baustoffen unter Schadstoffentfrachtung (insbes. Sulfat) des RCMaterials sowie ökobilanzieller Vergleich von Primär- und Sekundärrohstoffeinsatz inkl. Wiederverwertung. Umweltbundesamt, Umweltforschungsplan des Bundesministeriums für Umwelt, Naturschutz und Reaktorsicherheit, Forschungskennzahl 370933317, UBA-FB 001676, 05/2013.

Willkomm, W. 1990. Abbruch und Recycling. Verlag TÜV Rheinland, Köln, 1990.

Xanthopoulos, A., Aidonis, D., Vlachos, D., Iakovou, E., 2012. A planning optimisation framework for construction and demolition waste management. In: International Journal of Industrial and Systems Engineering, 10(3): 257-276. 